\title{
Blood lactate concentrations following maximal incremental test in male runners with different ages
}

http://dx.doi.org/10.11606/1807-5509201800010005

\author{
Cecília Segabinazi PESERICO* \\ Paulo Victor MEZZAROBA*** \\ Danilo Fernandes da SILVA ${ }^{* * *}$ \\ Ana Claudia Pelissari KRAVCHYCHYN**** \\ Júlio César Camargo ALVES ${ }^{* * * * *}$ \\ Fabiana Andrade MACHADO****
}

*Departament of

Physical Education

State University of

Maringá, Maringá,

PR, Brazil.

${ }^{* *}$ Departament of

Physical Education

Metropolitan

University Center of

Maringá, Maringá,

PR, Brazil.

***University of

Ottawa, Canada.

****Federal University

of São Paulo, São

Paulo, SP, Brazil.

${ }_{* * * * *}$ Departament of

Physical Education,

State University of

Minas Gerais, Belo

Horizonte, MG, Brazil.

\begin{abstract}
The aim of this study was to investigate the effect of age on peak blood lactate concentration following a maximal incremental treadmill test in male recreational runners. Seventy runners from four age groups, $\leq 25$ years; $26-35$ years; $36-45$ years; $>45$ years, performed an incremental treadmill test starting at $8 \mathrm{~km} \cdot \mathrm{h}^{-1}$, and increasing by $1 \mathrm{~km} \cdot \mathrm{h}^{-1}$ every three minutes until volitional exhaustion. Blood samples were collected at baseline and at the zero, third, fifth and seventh minutes after test to determine lactate concentrations. Peak lactate concentration $\left(\mathrm{LA}_{\text {peak }}\right)$ was defined for each participant as the highest value among the four samples. The lactate concentrations were influenced by the participants' age $(r=-0.47)$, with $L A_{\text {peak }}$ of the younger runners $\left(10.8 \pm 2.6 \mathrm{mmol} \cdot \mathrm{L}^{-1}\right)$ being higher than the values for the older age categories $(8.1 \pm 3.1$, $7.0 \pm 1.1$ and $6.9 \pm 2.8 \mathrm{mmol} \cdot \mathrm{L}^{-1}$ for those $26-35,36-45$ and $>45$ years, respectively). The $\mathrm{LA}_{\text {peak }}$ occurred more frequently at the third and fifth minute after the initiation of the test. In conclusion, the lactate concentrations were higher in the younger group $(<25)$ and reached peak more frequently at the third and fifth minute after the incremental test.
\end{abstract}

KeYwords: Physical Endurance; Lactic Acid; Exercise Test; Running.

\section{Introduction}

Variables obtained during incremental exercise tests, such as maximal heart rate $\left(\mathrm{HR}_{\max }\right)$, rate of perceived exertion (RPE) and peak blood lactate concentration $\left(\mathrm{LA}_{\text {peak }}\right)$ post-exercise are are considered surrogate measures of maximal oxygen uptake $\left(\mathrm{VO}_{2 \max }\right)$, which is reached in maximal effort, mainly when subjects fail to demonstrate a plateau in oxygen uptake during a maximal incremental test. In relation to $\mathrm{LA}_{\text {peak }}$ there are conflicting opinions related to the cut-off value of blood lactate concentration considered as an index of exhaustion ${ }^{1,2}$.

There are several values of post-exercise lactate concentration used as standards to indicate the maximal effort was achieved, but the most widely used is the concentration equal or above 8 $\mathrm{mmol} \cdot \mathrm{L}^{-1}{ }^{1}$. However this value is subject-specific and characteristics such as age, gender, level of training may influence them ${ }^{1-3}$. A recent study 
has suggested new values corresponding to $\mathrm{LA}_{\text {peak }}$ related to maximal effort for women $(\geq 3.5$ to $\geq 7.0$ $\left.\mathrm{mmol} \cdot \mathrm{L}^{-1}\right)$ and men $\left(\geq 4.0\right.$ to $\left.\geq 9.0 \mathrm{mmol} \cdot \mathrm{L}^{-1}\right)$ aged between 20 and 85 years old ${ }^{4}$.

Regarding the impact of the age, it was demonstrated that in older individuals, the lactate concentrations during and following exercise are generally lower than that of their younger counterparts ${ }^{3-5}$. EDVARDSEN et al. ${ }^{4}$ reported that, in healthy men and women aged 20-85 years, the LA $_{\text {peak }}$ after the Balke incremental protocol with walking and running decreases with increasing age; especially after the age of 50 years. MARSH et al. ${ }^{6}$

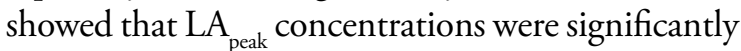
lower in men aged 60-70 years than in men aged 20-30 years after all-out 30-s cycle sprint. Similar results were observed by KORHONEN et al. ${ }^{5}$ who demonstrated an age-related decline in $\mathrm{LA}_{\text {peak }}$ in male and female sprinters. Thus, it does not seem adequate to use a standard value of $\mathrm{LA}_{\text {peak }}$ to indicate the attainment of maximal effort given the apparent dependence on specific subject characteristics.

Despite results indicating an association between $\mathrm{LA}_{\text {peak }}$ concentrations and age, following various performance tests in healthy non-athletes men and women ${ }^{4}$ and in sprinters ${ }^{5,6}$, to our knowledge there are no studies demonstrating an impact of aging on lactate concentrations in endurance athletes (e.g., long distance runners) after maximal incremental running tests. It is known that age may reduce phosphocreatine metabolism capacity and decrease rate of glycolysis, due to significant changes in the expression of enzymes related to glycolytic metabolism ${ }^{7}$. Age is also related to reduced muscle mass and structural changes, causing a selective atrophy in fast twitch fibers. In addition there is evidence to support fat and connective tissue infiltration in skeletal muscle, which could be favorable to a more oxidative muscle profile ${ }^{8,9}$. Considering that endurance training can lead to an even greater oxidative muscle profile, these factors together may play a role in the production and removal of lactate.

Therefore, the aim of this study was to investigate the impact of age on peak blood lactate concentration following maximal incremental test in male recreational runners. We hypothesized that the peak blood lactate concentration are influenced by the age.

\section{Methods}

\section{Participants}

Seventy male, recreational endurance-trained runners with experience racing at the $10-\mathrm{km}$ distance and involved in systematic training were recruited. They were all apparently healthy (i.e., absence of cardiovascular risk factors or respiratory diseases) based on anamneses made before starting the protocol. Characteristics of the participants (mean \pm SD) are presented in TABLE 4. Participants trained at a frequency of $4.1 \pm 1.7$ days $\cdot \mathrm{wk}^{-1}$ and logged, on average, a distance of $43.8 \pm 30.7 \mathrm{~km} \cdot \mathrm{wk}^{-1}$. The $10-\mathrm{km}$ running times of the participants were between 40 and $60 \mathrm{~min}$ (i.e., a pace between 10 and $15 \mathrm{~km} \cdot \mathrm{h}^{-1}$ $\approx 44-66 \%$ of the World record). Participants were divided into four groups according to age categories for non-masters (1 and 2) and masters categories ${ }^{10,11}$ (3 and 4) 1) $\leq 25$ years; 2) 26-35 years; 3) 36-45 years; 4$)>45$ years). The training experiences were: $3.0 \pm 1.9$ years; $5.6 \pm 3.4$ years; $6.5 \pm 6.1$ years and $19.2 \pm 14.2$ years each group $(\leq 25,26-35,36-45$, $>45$ years, respectively). This age stratification (i.e., 10-year age groups) was decided upon as it allowed for an equal distribution of participants and lactate responses; additionally, previous studies that analyzed the effect of age on peak lactate concentration used this same age stratification ${ }^{3,5}$. Before testing, written informed consent was obtained from all participants. The experimental protocol was approved by the university's ethics committee (\# 719/2010).

\section{Anthropometric measurements}

All the anthropometric measures were obtained in the laboratory before the incremental test and were made by a single assessor to minimize possible inter-tester errors. Body mass (BM) and height were measured using standardized procedures. Body mass was measured to the nearest $0.05 \mathrm{~kg}$ using a Filizola ${ }^{\oplus}$ scale with a capacity of measuring $150 \mathrm{~kg}$. Subjects were wearing light clothes and no shoes. Height was measured with a Seca ${ }^{\oplus}$ stadiometer to the nearest $0.05 \mathrm{~cm}$ and capacity of measuring $2 \mathrm{~m}$. Subjects were positioned in anatomic position and 
the reference being the distance between vertex and the plantar aspect of the foot. Skinfold measures were used to calculate body fat percentage $(\% \mathrm{BF})$ using a Harpenden skinfold caliper at seven sites: pectoral, triceps, abdominal, thigh, subscapular, suprailiac and midaxillary. Measures were taken at each site three times, adopting the average of these values as final value. Body density (BD) was determined using the seven skinfolds protocol of JACKSON and POLLOCK ${ }^{12}$. Subsequently, body fat percentage $(\% \mathrm{BF})$ was calculated from BD using Siri's equation ${ }^{13}$.

\section{Incremental exercise protocol}

After a warm-up, comprised walking at $6 \mathrm{~km} \cdot \mathrm{h}^{-1}$ for three minutes, the continuous protocol started with a speed of $8 \mathrm{~km} \cdot \mathrm{h}^{-1}$ and increased by $1 \mathrm{~km} \cdot \mathrm{h}^{-1}$ between each successive 3-minute stage until participants reached volitional exhaustion ${ }^{14}$. This protocol was chosen because, compared to shorter protocols (e.g., 1 and $2 \mathrm{~min}$ ), it was previously shown to have the highest correlations with endurance running performance in recreationally-trained runners ${ }^{14}$. This highly reliable protocol ${ }^{15}$ may also have greater practical implications for exercise training/ prescription. Participants were strongly encouraged, verbally, to invest maximum effort during each test. The tests were performed under normal laboratory conditions (temperature $=20-22^{\circ} \mathrm{C}$ and relative humidity $=50-60 \%)$. Participants were instructed to report for testing well-rested, nourished, and hydrated, wearing lightweight comfortable clothing. They were asked to avoid eating two hours before the maximal exercise test, to abstain from caffeine and alcohol, and to refrain from the training routines $48-\mathrm{h}$ before testing. All these conditions were confirmed by the participants prior the test.

Before testing, participants were introduced to the 6-20 Borg scale ${ }^{16}$, which was used to assess the rate of perceived exertion during the last $15 \mathrm{~s}$ of each stage and at volitional exhaustion. The highest RPE value was adopted as the peak RPE (RPE peak $\left._{\text {ear }}\right)$. Heart rate was recorded every five seconds through-out the tests (Polar RS800SD, Kempele, Finland) and the maximal heart rate $\left(\mathrm{HR}_{\text {max }}\right)$ was defined as the greatest rate during the tests ${ }^{17}$. Neither pulmonary gases nor blood lactate was assessed during the tests given that such assessments could affect the performance of the participants ${ }^{18,19}$. The peak running speed $\left(\mathrm{V}_{\text {peak }}\right)$ of the incremental test was calculated as the speed of the last complete stage added to the completed fraction of the incomplete stage ${ }^{20}$ calculated according to the equation
" $V_{\text {peak }}=V_{\text {complete }}+t / T$ ", in which $V_{\text {complete }}$ is the running speed of the last complete stage, $t$ the time in seconds sustained during the incomplete stage, and $\mathrm{T}$ the time in seconds required to complete a stage (i.e.180 s).

Maximal effort was deemed to have been achieved if the incremental test produced two of the following $\mathrm{VO}_{2 \max }$ criteria $^{14,15,21}$, 1) peak blood lactate concentration $\left.\geq 8 \mathrm{mmol} \cdot \mathrm{L}^{-122}, 2\right)$ maximum heart rate $\geq 95 \%$ of endurance-trained age-predicted maximum heart rate using the age-based $[206-(0.7 \times \text { age })]^{17}$ and 3 ) highest rating of perceived exertion value $\geq 19$ in the 6-20 Borg scale ${ }^{1}$.

\section{Lactate measurements}

Earlobe capillary blood samples $(25 \mu \mathrm{L})$ were collected into a capillary tube to determine the lactate concentrations. These samples were collected before $\left(\mathrm{LA}_{\mathrm{pre}}\right)$ and after the end of the maximal incremental test $\left(\mathrm{LA}_{0 \text {-min }}\right)$, and at the third $\left(\mathrm{LA}_{3-\min }\right)$, fifth $\left(\mathrm{LA}_{5 \text {-min }}\right)$ and seventh $\left(\mathrm{LA}_{7 \text {-min }}\right)$ minutes after test. Earlobe sample site is known to have a strong relationship with both venous blood ${ }^{23}$ and with fingertip blood samples ${ }^{24}$. For the LA $A_{\text {pre }}$, participants remained at rest for 15-min in a comfortable chair prior to the sampling procedure. For the blood samples taken post-test ( $\mathrm{LA}_{0 \text {-min, }}$, $\mathrm{LA}_{3-\text { min }}, \mathrm{LA}_{5 \text {-min }}, \mathrm{LA}_{7 \text {-min }}$ ) the participants remained standing upright on the treadmill. The samples were subsequently determined by electroenzymatic methods using the YSI 2300 STAT (Ohio, USA) automated analyzer (accuracy $\pm 2 \%$ ). Delta lactate $(\triangle \mathrm{LA})$ was determined as the difference between $\mathrm{LA}_{0 \text {-min }}, \mathrm{LA}_{3-\mathrm{min}}, \mathrm{LA}_{5-\mathrm{min}}, \mathrm{LA}_{7-\mathrm{min}}$ and LA $\mathrm{L}_{\text {pre }}$. The $\mathrm{LA}_{\text {peak }}$ was defined for each participant as the highest value among $\mathrm{LA}_{0-\text { min }}, \mathrm{LA}_{3-\min }, \mathrm{LA}_{5-\min }$, and $\mathrm{LA}_{7 \text {-min }}$.

\section{Statistical analyses}

Data are presented as mean \pm SD. These data were analyzed using the Statistical Package for the Social Sciences 17.0 software (SPSS Inc., USA). The ShapiroWilk test was used to check the normality of the data distribution, whereas homogeneity was tested by Levene test for equality of variance. The comparison between age categories for anthropometric parameters and variables obtained during maximal incremental test was made by One-way ANOVA. Mixed ANOVA for repeated measures was used to compare age groups (between-subjects) and the time points (withinsubjects) at which blood lactate concentration was determined. The sphericity assumption was checked by Mauchly's test of sphericity and, where violations 
occurred, degrees of freedom were corrected using Greenhouse-Geisser (epsilon $\leq 0.75$ ) or Huynd-Feldt (epsilon > 0.75) estimates of sphericity. Bonferroni post hoc testing was used for multiple comparisons. The relationship between age and peak blood lactate concentration was analyzed by linear regression and were qualitatively classified according to Hopkins et al. ${ }^{25}$ as trivial $(<0.1)$, small (between 0.1 and 0.29), moderate (between 0.3 and 0.49 ), large (between 0.5 and 0.69 ), very large (between 0.7 and 0.89 ) and almost perfect (between 0.9 and 1.0). Statistical significance was set at $P<0.05$.

\section{Results}

Sixty-six participants met the criteria for maximal effort in the incremental test, and the four who did not meet at least two criteria were excluded from the results.

\section{The blood lactate results}

The blood lactate concentrations post maximal incremental test $\left(\mathrm{LA}_{0 \text {-min }}, \mathrm{LA}_{3 \text {-min }}, \mathrm{LA}_{5-\text { min }}\right.$ and $\left.\mathrm{LA}_{7 \text {-min }}\right)$ by age groups are presented in FIGURE 1 . The mixed ANOVA for repeated measures revealed a significant effect of time on the lactate concentrations $(P<$ 0.001 ). Additionally, a significant interaction between age category and time was identified $(P<0.001)$. The
ANOVA showed that $\mathrm{LA}_{0 \text {-min }}(P<0.001), \mathrm{LA}_{5-\text { min }}$ $(P<0.001)$ and $\mathrm{LA}_{7-\min }(P<0.001)$ were different between the younger group and all other groups; the $\mathrm{LA}_{3-\min }$ differed between younger runners and 36-45 years $(P=0.001)$ and $>45$ years $(P=0.002)$ groups, highlighting higher lactate values for the group of $\leq 25$ years. Post exercise lactate concentrations were higher than the LA for all age groups $(P<0.001)$; $\mathrm{LA}_{0 \text {-min }}$ was lower than $\mathrm{LA}_{5 \text {-min }}$ in the groups of $\leq 25$ years $(P=0.036)$ and $36-45$ years $(P=0.023)$; further, only in the group of 26-35 years the $\mathrm{LA}_{3 \text {-min }}$ differed from other measurement time points $(P<0.001$, $P<0.001, P=0.009, P=0.001$, respectively).
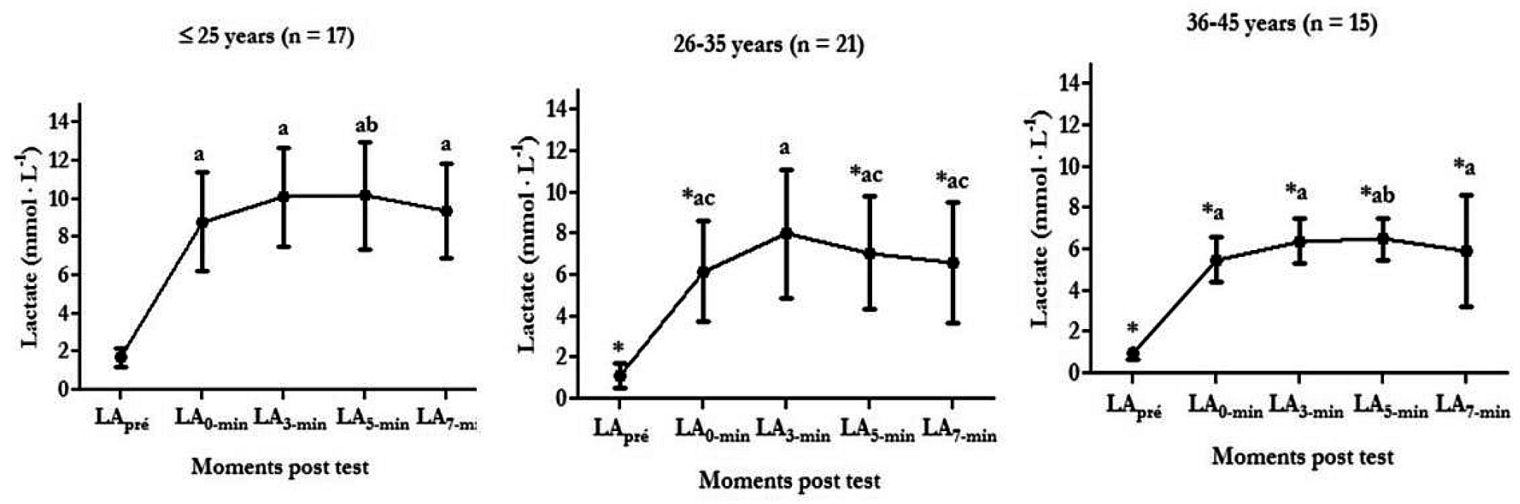

Notes: ${ }^{*} P<0.05$

compared to $\leq 25$ years; $\# P<0.05$ compared to

$26-35$ years; ${ }^{\dagger} P<0.05$ compared to $36-45$ years; ${ }^{\text {a }} P<0.05$ compared to $L A_{\text {,re }}$, $P<0.05$ compared to $L A_{0-\min } ;{ }^{c} P<0.05$ compared to $\mathrm{LA}_{3-\mathrm{min}} ;{ }^{\mathrm{d}}$ $P<0.05$ compared to $\mathrm{LA}_{5-\mathrm{min}}$.
$>45$ years $(n=13)$

Total $(n=66)$
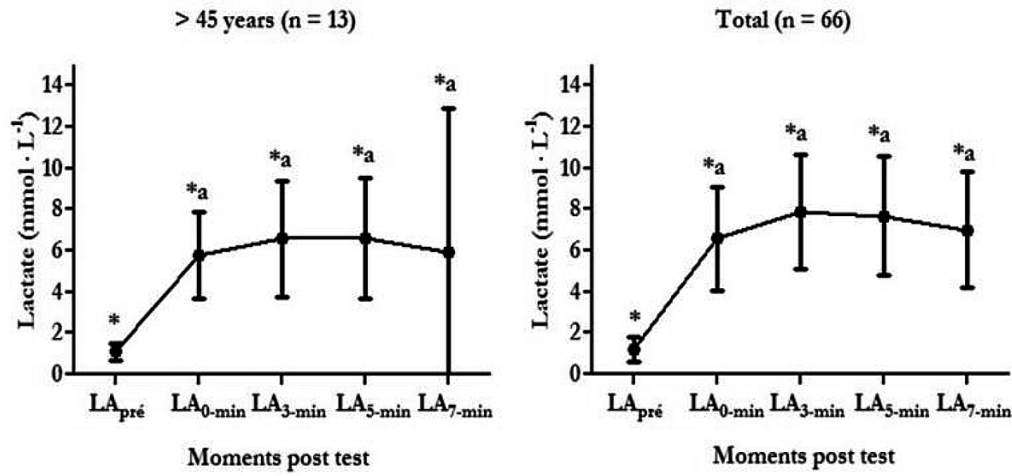

FIGURE 1 - Post-exercise blood lactate concentration $\left(\mathrm{mmol} \cdot \mathrm{L}^{-1}\right)$ after maximal incremental test for runners according to age categories. 
TABLE 1 presents LA $\mathrm{A}_{\text {peak }}$ and delta blood lactate concentration for each age group. For the LA $A_{\text {peak }}$ values, the younger runners demonstrated the highest values, which were significantly different from the 26-35 years $(P=0.013), 36-45$ years $(P=0.001)$ and $>45$ years $(P=0.001)$. Regarding the delta lactate, Mixed ANOVA results showed significant effect of time $(P<0.001)$ but no interaction between age category and time $(P=0.241)$. The mean \pm SD for $\mathrm{LA}_{\text {pre }}$ values were: $1.7 \pm 0.5$ ( $\leq 25$ years), $1.1 \pm 0.6$ ( $26-35$ years), $1.0 \pm 0.3$ (36-45 years), $1.1 \pm 0.4$ (< 45 years) and $1.2 \pm 0.6 \mathrm{mmol} \cdot \mathrm{L}^{-1}$ (total sample). ANOVA analyses indicated that the $\Delta \mathrm{LA}_{0-\text { min, }} \Delta \mathrm{LA}_{5 \text {-min }}$ and $\Delta \mathrm{LA}_{7 \text {-min }}$ were different between the younger group and all other groups $\left(P<0.001\right.$ for all). The $\Delta \mathrm{LA}_{3-\min }$ of the younger group differed from the group of $36-45$ years $(P=0.001)$ and from the older group $(P=0.002)$. Regarding the moments of measurement, for the younger group the $\triangle \mathrm{LA}_{0 \text { - }}$ ${ }_{\text {min }}$ was lower than $\Delta \mathrm{LA}_{3 \text {-min }}(P=0.031)$ and
$\Delta \mathrm{LA}_{5 \text {-min }}(P=0.021)$; for the group of $26-35$ years the $\Delta \mathrm{LA}_{3-\text { min }}$ was higher than $\Delta \mathrm{LA}_{0-\text { min }}$ $(P<0.001), \Delta \mathrm{LA}_{5-\text { min }}(P=0.005)$ and $\Delta \mathrm{LA}_{7 \text {-min }}$ $(\mathrm{P}<0.001)$; for the group of $36-45$ years only the $\Delta \mathrm{LA}_{0 \text {-min }}$ differed from $\Delta \mathrm{LA}_{5 \text {-min }}(\mathrm{P}=0.014)$; for the total sample, the $\Delta \mathrm{LA}_{0-\min }$ and $\Delta \mathrm{LA}_{7-\min }$ were lower than $\Delta \mathrm{LA}_{3 \text {-min }}(P<0.001$ and $P<0.001$, respectively $)$ and $\Delta \mathrm{LA}_{5-\min }(P<0.001$ and $P<0.001$, respectively).

Regarding the moment that the blood lactate concentration reached peak, it occurred more frequently at the third minute $\left(\mathrm{LA}_{3-\mathrm{min}}\right)$ after the incremental test in the groups of 26-35 years, $36-45$ years and in the total sample. The younger and older group demonstrated the same frequency at the third and fifth $\left(\mathrm{LA}_{5-\min }\right)$ minutes after the incremental test for the $\mathrm{LA}_{\text {peak }}$ occurrence. The lowest frequency for the postexercise lactate concentration occurred at the end of the incremental test $\left(\mathrm{LA}_{0 \text {-min }}\right)$ or at the seventh $\left(\mathrm{LA}_{7-\mathrm{min}}\right)$ in all groups.

TABLE 1 - Peak blood lactate concentration and delta blood lactate concentration (mmol $\cdot \mathrm{L}^{-1}$ ) response to the maximal incremental test for runners according to age categories.

\begin{tabular}{lccccc}
\hline Variables & $\begin{array}{c}\mathbf{2 5} \text { years } \\
(\mathbf{n}=\mathbf{1 7})\end{array}$ & $\begin{array}{c}\mathbf{2 6 - 3 5} \text { years } \\
(\mathbf{n}=\mathbf{2 1})\end{array}$ & $\begin{array}{c}\mathbf{3 6 - 4 5} \text { years } \\
(\mathbf{n}=\mathbf{1 5})\end{array}$ & $\begin{array}{c}>45 \text { years } \\
(\mathbf{n}=\mathbf{1 3})\end{array}$ & $\begin{array}{c}\text { Total } \\
(\mathbf{n}=\mathbf{6 6})\end{array}$ \\
\hline $\mathrm{LA}_{\text {peak }}\left(\mathrm{mmol} \cdot \mathrm{L}^{-1}\right)$ & $10.8 \pm 2.6$ & $8.1 \pm 3.1^{*}$ & $7.0 \pm 1.1^{*}$ & $6.9 \pm 2.8^{*}$ & $8.3 \pm 3.0$ \\
$\Delta \mathrm{LA}_{0 \text {-min }}$ & $7.1 \pm 2.4$ & $5.1 \pm 2.0^{*}$ & $4.5 \pm 1.1^{*}$ & $4.7 \pm 2.0^{*}$ & $5.4 \pm 2.2$ \\
$\Delta \mathrm{LA}_{3 \text {-min }}$ & $8.4 \pm 2.0^{\mathrm{a}}$ & $7.0 \pm 2.7^{\mathrm{a}}$ & $5.5 \pm 1.2^{*}$ & $5.4 \pm 2.7^{*}$ & $6.7 \pm 2.5^{\mathrm{a}}$ \\
$\Delta \mathrm{LA}_{5 \text {-min }}$ & $8.5 \pm 2.6^{\mathrm{a}}$ & $6.0 \pm 2.4^{\mathrm{b},{ }^{*}}$ & $5.6 \pm 1.1^{\mathrm{a},{ }^{*}}$ & $5.5 \pm 2.7^{*}$ & $6.5 \pm 2.6^{\mathrm{a}}$ \\
$\Delta \mathrm{LA}_{7-\text { min }}$ & $7.7 \pm 2.3$ & $5.6 \pm 2.6^{\mathrm{b},{ }^{*}}$ & $4.9 \pm 1.7^{*}$ & $4.8 \pm 2.5^{*}$ & $5.8 \pm 2.5^{\mathrm{b}, \mathrm{c}}$ \\
\hline
\end{tabular}

TABLE 2 - Frequency (relative and absolute) of the moment at which participants reached peak lactate concentration after incremental test for the age groups.

\begin{tabular}{lccccc}
\hline Variables & $\begin{array}{c}\leq \mathbf{2 5} \text { years } \\
(\mathbf{n}=\mathbf{1 7})\end{array}$ & $\begin{array}{c}\mathbf{2 6 - 3 5} \text { years } \\
(\mathbf{n}=\mathbf{2 1})\end{array}$ & $\begin{array}{c}\mathbf{3 6 - 4 5} \text { years } \\
(\mathbf{n}=\mathbf{1 5})\end{array}$ & $\begin{array}{c}>45 \text { years } \\
(\mathbf{n}=\mathbf{1 3})\end{array}$ & $\begin{array}{c}\text { Total } \\
(\mathbf{n}=\mathbf{6 6})\end{array}$ \\
\hline $\mathrm{LA}_{0 \text {-min }}$ & $11.8(\mathrm{n}=2)$ & $4.8(\mathrm{n}=1)$ & $13.3(\mathrm{n}=2)$ & $15.4(\mathrm{n}=2)$ & $10.6(\mathrm{n}=7)$ \\
$\mathrm{LA}_{3-\text { min }}$ & $41.2(\mathrm{n}=7)$ & $76.2(\mathrm{n}=16)$ & $40.0(\mathrm{n}=6)$ & $30.8(\mathrm{n}=4)$ & $50.0(\mathrm{n}=33)$ \\
$\mathrm{LA}_{5 \text {-min }}$ & $41.2(\mathrm{n}=7)$ & $14.3(\mathrm{n}=3)$ & $26.7(\mathrm{n}=4)$ & $30.8(\mathrm{n}=4)$ & $27.3(\mathrm{n}=18)$ \\
$\mathrm{LA}_{7-\text { min }}$ & $5.9(\mathrm{n}=1)$ & $4.8(\mathrm{n}=1)$ & $20.0(\mathrm{n}=3)$ & $23.1(\mathrm{n}=3)$ & $12.1(\mathrm{n}=8)$ \\
\hline
\end{tabular}

$\mathrm{LA}_{\text {peak }}$, peak blood lactate concentration; $\Delta \mathrm{LA}$, difference between $L A$, $\mathrm{LA}_{3-\min }, \mathrm{LA}_{5-\mathrm{min}}$, and $L A_{7-\min }^{3-\min }$ with $L A_{\text {pre }}^{5}$; ${ }^{*} P<0.05$ compared to $\leq 25$ years;

${ }^{\#} P<0.05$ compared to $26-35$ years; $+P<0.05$ compared to $36-45$ years; a $P<0.05$ compared to $\Delta \mathrm{LA}_{0-\min } ;{ }^{\text {b }} P<0.05$ compared to $\Delta \mathrm{LA}_{3-\mathrm{min}}$ ${ }^{\mathrm{c}} P<0.05$ compared to $\Delta \mathrm{LA}_{5-\min }$.
The FIGURE 2 demonstrates the relationship between age and $\mathrm{LA}_{\text {peak }}$ for each age group and for all sample together (i.e., total sample size). Only the correlation for the group of 26-35 years and for the total sample were significant $(P=0.017$ and $P<0.001$, respectively); additionally, these correlations were negative and higher than others, in which the classification of -0.51 was large and -0.47 was moderate. These results emphasize that as age increases, $\mathrm{LA}_{\text {peak }}$ tends to be lower. 

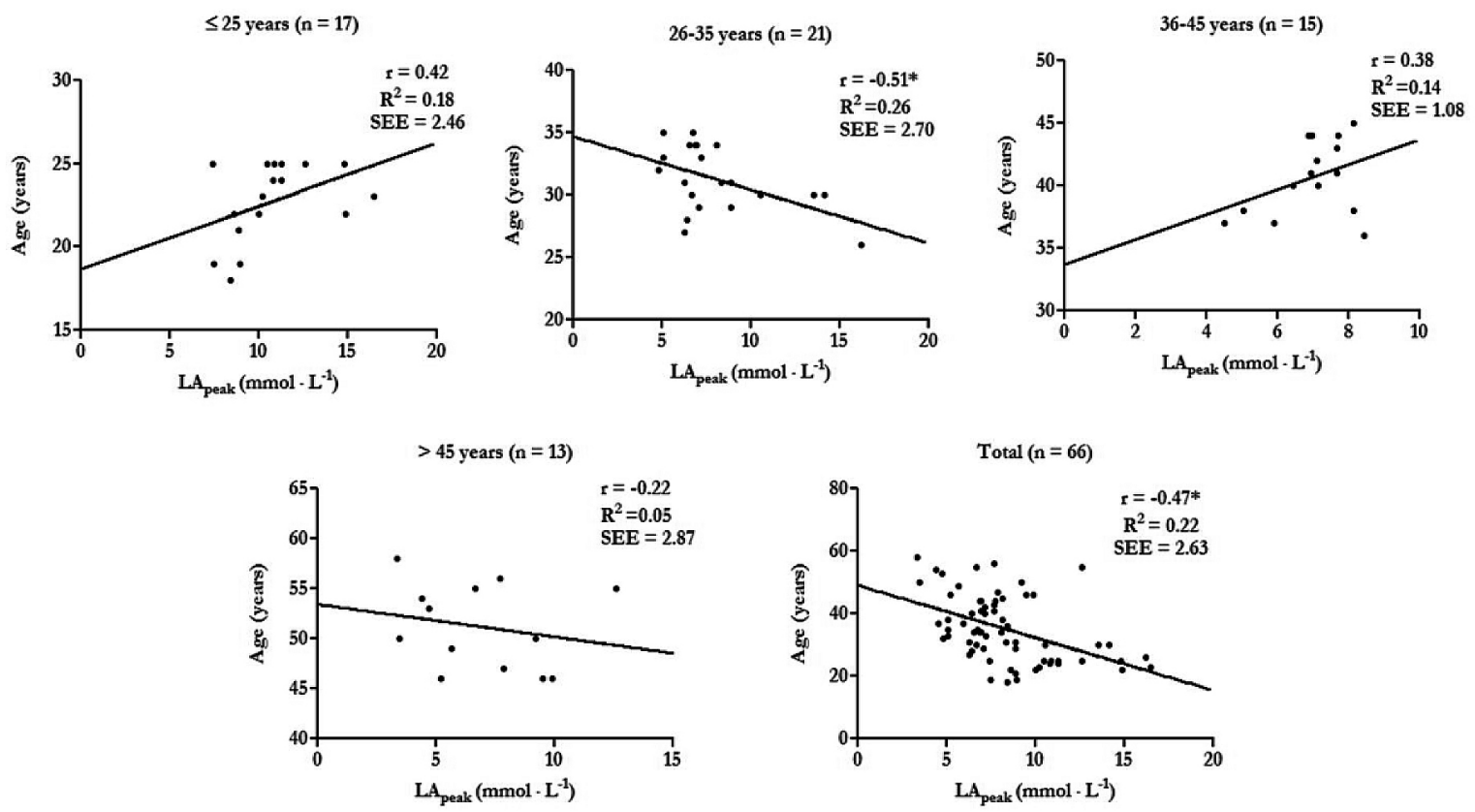

FIGURE 2 - Relationship between peak blood lactate concentrations and age. The solid line represents the linear regression. Notes: r, correlation coefficient; $\mathrm{R}^{2}$, coefficient of determination, SEE, standard error of estimate. ${ }^{*} P<0.05$.

\section{Maximal incremental test results}

The variables obtained during the maximal incremental test (mean \pm SD) for the different age groups are presented in TABLE 3. The $\mathrm{HR}_{\max }$ of the older group differed from all other age groups $(P<0.001)$; additionally, the younger group presented higher $\mathrm{HR}_{\max }$ than the group of 36-45 years $(P=0.004)$. The $\%$ APMHR and $\mathrm{RPE}_{\max }$ not differed between age groups.
$V_{\text {peak }}$, peak running speed; $H_{\text {max }}$ maximal heart rate; $\% A P M H R$, percentage of age-predicted maximum heart rate; $\mathrm{RPE}_{\text {peak }}$, peak rating of perceived exertion; * $P<0.05$ compared to $\leq 25$ years; ${ }^{*} P<0.05$ compared to $26-35$ years; ${ }^{\dagger} P<0.05$ compared to $36-45$ years

TABLE 3 - Comparison among age groups for variables obtained during maximal incremental test.

\begin{tabular}{lccccc}
\hline Variables & $\begin{array}{c}\mathbf{2 5} \text { years } \\
(\mathbf{n}=\mathbf{1 7})\end{array}$ & $\begin{array}{c}\mathbf{2 6 - 3 5} \text { years } \\
(\mathbf{n}=\mathbf{2 1})\end{array}$ & $\begin{array}{c}\mathbf{3 6 - 4 5} \text { years } \\
(\mathbf{n}=\mathbf{1 5})\end{array}$ & $\begin{array}{c}>45 \text { years } \\
(\mathbf{n}=\mathbf{1 3})\end{array}$ & $\begin{array}{c}\text { Total } \\
(\mathbf{n}=\mathbf{6 6})\end{array}$ \\
\hline $\mathrm{V}_{\text {peak }}\left(\mathrm{km} \cdot \mathrm{h}^{-1}\right)$ & $15.1 \pm 1.3$ & $15.8 \pm 1.7$ & $15.2 \pm 1.7$ & $16.3 \pm 1.4$ & $15.6 \pm 1.6$ \\
$\mathrm{HR}_{\text {max }}\left(\mathrm{b} \cdot \mathrm{min}^{-1}\right)$ & $192.0 \pm 8.7$ & $187.0 \pm 7.2$ & $182.3 \pm 7.8^{*}$ & $169.5 \pm 7.1^{* * \dagger}$ & $183.8 \pm 10.9$ \\
$\% \mathrm{APMHR}(\%)$ & $101.1 \pm 4.4$ & $101.6 \pm 3.9$ & $102.7 \pm 5.0$ & $99.6 \pm 3.7$ & $101.3 \pm 4.3$ \\
$\mathrm{RPE}_{\max }(6-20)$ & $19.2 \pm 0.8$ & $19.4 \pm 0.6$ & $19.5 \pm 0.6$ & $19.8 \pm 0.8$ & $19.4 \pm 0.7$ \\
\hline
\end{tabular}

\section{Anthropometric parameters results}

The comparisons among age groups for the anthropometric parameters (mean $\pm \mathrm{SD}$ ) are given in TABLE 4 . The mean age was significantly different among the four groups $(P<0.001)$. Body mass was different between the older group ( $>45$ years) and groups of 26-35 years $(P=0.001)$ and $36-45$ years $(P=0.023)$; regarding the height, the older group differed from the younger group $(\leq 25$ years $)$ $(P=0.018)$ and from the group of $26-35$ years $(P=0.023)$. 
TABLE 4 - Comparison among age groups for anthropometric parameters.

\begin{tabular}{lccccc}
\hline Variables & $\begin{array}{c}\leq \mathbf{2 5} \text { years } \\
(\mathbf{n}=\mathbf{1 7})\end{array}$ & $\begin{array}{c}\mathbf{2 6 - 3 5} \text { years } \\
(\mathbf{n = 2 1})\end{array}$ & $\begin{array}{c}\mathbf{3 6 - 4 5} \text { years } \\
(\mathbf{n}=\mathbf{1 5})\end{array}$ & $\begin{array}{c}>45 \text { years } \\
(\mathbf{n}=\mathbf{1 3})\end{array}$ & $\begin{array}{c}\text { Total } \\
(\mathbf{n}=\mathbf{6 6})\end{array}$ \\
\hline Age & $22.7 \pm 2.3$ & $31.2 \pm 2.7^{*}$ & $40.7 \pm 3.0^{* \#}$ & $51.2 \pm 4.2^{* \# \dagger}$ & $35.1 \pm 10.6$ \\
Body mass $(\mathrm{kg})$ & $73.3 \pm 6.6$ & $77.0 \pm 9.2$ & $74.9 \pm 9.7$ & $65.2 \pm 8.0^{\# \dagger}$ & $73.3 \pm 9.3$ \\
Height $(\mathrm{cm})$ & $178.1 \pm 6.5$ & $177.6 \pm 5.7$ & $176.7 \pm 7.3$ & $170.5 \pm 7.4^{* \#}$ & $176.1 \pm 7.1$ \\
Body Fat $(\%)$ & $13.1 \pm 3.0$ & $11.7 \pm 3.6$ & $12.5 \pm 4.4$ & $14.9 \pm 3.9$ & $12.9 \pm 3.8$ \\
\hline
\end{tabular}

\section{Discussion}

The present study aimed to investigate the impact age on peak blood lactate concentration following maximal incremental test in male recreational runners. The main findings were that the lactate concentrations were influenced by the age, with $\mathrm{LA}_{\text {peak }}$ of the younger runners being higher than the older groups of runners. Additionally, the highest percentage of the runners reached $\mathrm{LA}_{\text {peak }}$ at the third or at the fifth minutes after the incremental test, suggesting that the lactate samples should be taken at both minute three and five post-exercise to ensure that peak lactate value is obtained even with an individual variation.

Many studies have used secondary criteria to indicate attainment of $\mathrm{VO}_{2 \max }$ during a maximal incremental test ${ }^{2,14,26}$. These criteria include a rating of perceived exertion and post-exercise blood lactate levels usually above or equal 19 and $8 \mathrm{mmol} \cdot \mathrm{L}^{-1}$, respectively, and an increase in heart rate to maximal values estimated by age ${ }^{1}$. However, it is important to emphasize that all of these standard values were derived from studies which used specific subjects and test protocols (i.e., discontinuous protocols). Thus directly applying these criteria to studies with different methodogy and subjects may result in misinterpretation ${ }^{1,27}$.

Some researchers criticize the use of HR and RPE as secondary criteria for maximal effort ${ }^{2,27}$ because these variables are influenced by many different factors during exercise, such as psychological, environmental and personal aspects ${ }^{2,28,29}$. However, our results showed that the criteria of maximal heart rate equal or above $95 \%$ of endurance-trained age-predicted maximum heart rate (\%APMHR) and the highest rating of perceived exertion value equal or above 19 were achieved for $95.5 \%$ and $90.9 \%$ of participants, respectively. Thus, both these criteria seem to be applicable in endurance runners regardless age. It is important to mention that we did not control for the psychosocial factors that could influence in maximal effort; however, this is a homogeneous sample regarding their health conditions (based on anamneses made before starting the protocol) and they were all used to running for recreational purposes.

In our study, different from the other two secondary criteria applied that were achieved for almost all participants, the $8 \mathrm{mmol} \cdot \mathrm{L}^{-1}$ blood lactate concentration criterion was reached only by $45.5 \%$ of the total sample. EDVArdsen et al. ${ }^{4}$ evaluated the $\mathrm{LA}_{\text {peak }}$ after the Balke test in 861 individuals aged $20-85$ years and reported that the $8 \mathrm{mmol} \cdot \mathrm{L}^{-1}$ criterion excluded $63 \%$ of the participants in the 50-85-year-old group. The authors reported that the $\mathrm{LA}_{\text {peak }}$ values were age and sex dependent. Duncan et al. ${ }^{27}$ investigated the incidence of achievement of secondary $\mathrm{VO}_{2 \max }$ criteria in 10 males during continuous and discontinuous incremental tests and, in contrast to our findings, demonstrated that the blood lactate criterion of $8 \mathrm{mmol} \cdot \mathrm{L}^{-1}$ were achieved by $100 \%$ and $90 \%$ of the subjects on the discontinuous and continuous protocols, respectively. However, it is important to emphasize that younger subjects as used in the study by Duncan et al. ${ }^{27}$, seem to reach the peak lactate concentration more easily than the older ones, as seen in our study comparing the age groups. This means that some subjects may not satisfy a particular criterion even when a maximal effort is given, which can be explained by the large inter-subject variation ${ }^{2}$.

Different protocol designs also could influence the response of lactate concentrations post incremental tests ${ }^{26,27}$. For example, Duncan et al. ${ }^{27}$ found greater blood lactate concentrations after a discontinuous protocol compared to a continuous protocol. MACHADO et al. ${ }^{26}$, compared the responses of LA ${ }_{\text {peak }}$ during maximal incremental treadmill tests of 1-min, 2-min, and 3-min stage durations and found lower concentration in the long-stage compared to the short-stage and intermediate-stage
${ }^{*} P<0.05$ compared to $\leq 25$ years; ${ }^{\#} P<$ 0.05 compared to 26 35 years; ${ }^{\dagger} P<0.05$ compared to $36-45$ years. 
protocols. However, these previous studies ${ }^{26,27,30}$

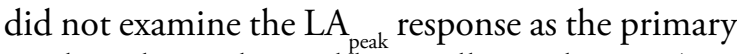
result and were limited by small sample sizes (i.e., less than 34 participants), unlike our study which used a sample size two times bigger (i.e., 70 runners) and examined different age categories.

Besides the influence of the protocol on the lactate concentrations, aging also appears to modify the lactate behaviour following maximal exercise $e^{3-6}$. BenELLI et al. ${ }^{3}$ verified a steep reduction in $\mathrm{LA}_{\text {peak }}$ concentrations as age increase in men aged 40-79 years after short and medium swimming performance. Similarly, KorHONEN et al. ${ }^{5}$ showed that there is an age-related decline in LA $_{\text {peak }}$ in sprinter male and female runners aged 35-88 years, and they found that the younger runners presented higher LA ${ }_{\text {peak }}$ after all performances than older runners in both sexes. Recently, Edvardsen et al. ${ }^{4}$ showed that the $\mathrm{LA}_{\text {peak }}$ decreases with increasing age and they recommended new lactate concentrations criterion for maximal effort according to age in male: $20-49$ years $\geq 9.0 \mathrm{mmol} \cdot \mathrm{L}^{-1}, 50-64$ years $\geq 6.0 \mathrm{mmol} \cdot \mathrm{L}^{-1} ; \geq 65$ years $\geq 4.0 \mathrm{mmol} \cdot \mathrm{L}^{-1}$. Despite the large sample, this study ${ }^{4}$ has some important limitations; i) the blood lactate samples were collected at only one time point 60 s after the test to determine the $\mathrm{LA}_{\text {peak }}$ and ii) used two different equipment to determine the lactate concentrations which may have influenced the results.

As far as could be determined, there has been no study examining the relationship between age and lactate concentrations after a maximal incremental test in male endurance runners. Some studies assessed endurance runners with mean age under 35 years and verified $\mathrm{LA}_{\text {peak }}$ concentrations ranging from 10.8 to $14.3 \mathrm{mmol} \cdot \mathrm{L}^{-120,27,30}$, while MACHADO et al. ${ }^{14,26}$ evaluated endurance runners with mean age above 35 years and found LA ${ }_{\text {peak }}$ concentrations ranging from 7.6 to $9.4 \mathrm{mmol} \cdot \mathrm{L}^{-1}$. Collectively, these studies support our findings that younger runners have higher $\mathrm{LA}_{\text {peak }}$ concentrations following incremental test compared to older ones. However, the comparative interpretation of these studies should be done with caution because there are differences between exercise mode, duration and blood lactate collection which could influence it.

It is already known that the natural aging process modifies the capacity of muscles to produce energy through the anaerobic system ${ }^{4,5}$. During childhood and adolescence, the maturation process of anaerobic enzymes, modifications on body composition and hormonal production leads to an increase in the ability or capacity to produce energy through the lactate pathway energy system, such changes are inverted during adulthood and consequently the lactate production seems to reduce with age advancing ${ }^{31-32}$.

Aging modifies body composition (e.g., muscle mass) and muscle structure through a selective atrophy in fast twitch muscle fibers, and a fat and connective tissue infiltration, leading to a shift toward a more oxidative muscle profile ${ }^{8,9}$. There is also a reduced phosphocreatine metabolism capacity and a decreased rate of glycolysis, due to great changes in the expression of enzymes related to glycolytic metabolism, especially the phosphofructokinase ${ }^{7}$. A reduction in the ability to perform exercises requiring high strength and power levels ${ }^{9,33,34}$ could also contribute to the age related decline in anaerobic metabolic capacity considering an adult sample. Therefore, these factors may play a role in the production and removal of lactate and could change lactate concentrations as observed in the comparison of the age groups of runners.

Regarding the timeframe at which the blood lactate concentration reached peak after the maximal incremental tests, we observed that the higher lactate concentrations occurred at the third or fifth minutes after the test. MACHADO et al. ${ }^{26}$ compared LA ${ }_{\text {o-min' }}$, $\mathrm{LA}_{3 \text {-min }}, \mathrm{LA}_{5 \text {-min }}$, and $\mathrm{LA}_{7 \text {-min }}$ after incremental tests and showed that the fifth minute was the moment at which the LA $A_{\text {peak }}$ concentrations were higher in 34 endurance runners. Gass et al. ${ }^{30}$ verified the blood lactate concentration each minute during 30 minutes after an incremental test and reported no difference in lactate concentrations for the fourth, fifth and sixth minutes after an incremental test in 13 trained subjects, indicating that these post-exercise moments are adequate to determine the $\mathrm{LA}_{\text {peak }}$. Thus, it is important to emphasize that adding our findings with these previous results, it is suggested that the lactate samples should be taken at both third and fifth minute after the incremental test to ensure the right $\mathrm{LA}_{\text {peak }}$ value.

Moreover, it is important to highlight some others limitations of using lactate concentrations as standard parameter to $\mathrm{VO}_{2 \max }$ determination and consequently in defining maximal effort. Many factors such as diet (nutrition) and hormonal conditions of the participants influence on the lactate metabolism, in the glycogen level available before the test, and, consequently, the lactate concentrations after the test ${ }^{35,36}$. However, despite nutritional recommendations, one of 
the limitations of the present study was a lack of diet control through the dietary recall, and the assessment of hormonal conditions of the participants before the tests. Furthermore, despite presenting greater percentage of achievement, the other two criteria used to consider maximal effort (e.g., HR and RPE) are also criticized in the literature, based on the influence they could suffer from psychological, environmental and personal aspects ${ }^{2,28,29}$, which were not appropriately controlled in the study (e.g., questionnaires application) and can be considered a limitation. However, the focus for this current study was to assess peak lactate concentrations in endurance runners and the possible influence of age.

We used the stage duration of three minutes for the incremental test, which presented higher correlation with endurance performance (compared to 1 and 2 minutes of stage duration), a test which is highly reliable and could have greater practical application for exercise training/prescription, ${ }^{14,15}$ the longer duration would be associated with lower peak lactate concentrations which may be consider another limitation ${ }^{26}$, given that maximal effort (e.g., $\mathrm{V}_{\text {peak }}$ at treadmill) is strongly dependent of the protocol ${ }^{21,26}$.

In conclusion the lactate concentrations after maximal incremental test were influenced by the age, with values being higher in the younger group with $\leq 25$ years than the older groups of runners and it was demonstrated a negative correlation with age and $\mathrm{LA}_{\text {peak }}$. Additionally, LA peak $_{\text {reached peak more }}$ frequently at the third and fifth minute after the incremental test vs. immediately after the test or at the seventh minute. We suggest that further studies are needed to assess the lactate response following maximal incremental test in different populations and modes of exercise, as well as also look more rigorously at other parameters used as criteria for maximal effort.

\section{Resumo}

Concentrações de lactato sanguíneo após teste incremental máximo em corredores com diferentes idades

0 objetivo deste estudo foi investigar o efeito da idade sobre a concentração pico de lactato após teste incremental máximo em corredores recreacionais. Setenta corredores foram recrutados. Os quatro grupos foram: $\leq 25$ anos; $26-35$ anos; $36-45$ anos; $>45$ anos). 0 s participantes realizaram um teste incremental com início a $8 \mathrm{~km} \cdot \mathrm{h}^{-1}$, incrementos de $1 \mathrm{~km} \cdot \mathrm{h}^{-1}$ a cada três minutos até exaustão voluntária. Amostras sanguíneas foram coletadas antes e nos minutos zero, terceiro, quinto e sétimo após o teste para a determinação das concentrações de lactato. A concentração pico de lactato $\left(L A_{\text {pico }}\right)$ foi definida para cada participante como o maior valor entre as quatro amostras coletadas após o teste. As concentrações de lactato foram influenciadas pela idade, no qual os valores de $L A_{\text {pico }}$ dos corredores mais novos $\left(10,8 \pm 2,6 \mathrm{mmol} \cdot \mathrm{L}^{-1}\right)$ foram maiores dos que os valores dos outros corredores $\left(8,1 \pm 3,1 ; 7,0 \pm 1,1 ; 6,9 \pm 2,8 \mathrm{mmol} \cdot \mathrm{L}^{-1}\right.$ para os grupos com idades de 26-35, 36-45 anos e 45 anos, respectivamente). $0 \mathrm{LA}_{\text {pico }}$ ocorreu mais frequentemente no terceiro e quinto minuto após o teste. Em conclusão, as concentrações de lactato após o teste incremental foram influenciadas pela idade, com maiores valores no grupo de corredores com idade $\leq 25$ anos do que os outros grupos. Além disso, o $\mathrm{LA}_{\text {pico }}$ ocorreu mais frequentemente no terceiro e quinto minutos após o teste incremental.

Palavras-Chave: Resistência Física; Ácido Láctico; Teste de Exercício; Corrida.

\section{References}

1. Howley ET, Bassett DR Jr, Welch HG. Criteria for maximal oxygen uptake: review and commentary. Med Sci Sports Exerc. 1995;27(9):1292-301.

2. Midgley AW, McNaughton LR, Polman R, Marchant D. Criteria for determination of maximal oxygen uptake: a brief critique and recommendations for future research. Sports Med. 2007;37(12):1019-28. 
3. Benelli P, Ditroilo M, Forte R, De Vito G, Stocchi V. Assessment of post-competition peak blood lactate in male and female master swimmers aged 40-79 years and its relationship with swimming performance. Eur J Appl Physiol. 2007;99(6):685-93.

4. Edvardsen E, Hem E, Anderssen SA. End criteria for reaching maximal oxygen uptake must be strict and adjusted to sex and age: a cross-sectional study. PloS One. 2014;9(1):e85276.

5. Korhonen MT, Suominen H, Mero A. Age and sex differences in blood lactate response to sprint running in elite master athletes. Can J Appl Physiol. 2005;30(6):647-65.

6. Marsh GD, Paterson DH, Govindasamy D, Cunningham, DA. Anaerobic power of the arms and legs of young and older men. Exp Physiol. 1999;84(3):589-97.

7. Hunter GR, Newcomer BR, Weinsier RL, Karapondo, DL, Larson-Meyer, DE, Joanisse, DR, et al. Age is independently related to muscle metabolic capacity in premenopausal women. J Appl Physiol. 2002;93(1):70-6.

8. Porter, MM, Vandervoort AA, Lexell J. Aging of human muscle: structure, function and adaptability. Scand J Med Sci Sports. 1995;5(3):129-42.

9. Macaluso A, De Vito G. Muscle strength, power and adaptations to resistance training in older people. Eur J Appl Physiol. 2004;91(4):450-72.

10. Reaburn P, Dascombe B. Endurance performance in master athletes. Eur Rev Aging Phys Act. 2008;5(1):31-42.

11. Knechtle B, Rüst CA, Knechtle P, Rosemann T. Does muscle mass affect running times in male long-distance master runners? Asian J Sports Med. 2012;3(4):247-56.

12. Jackson AS, Pollock ML. Generalized equations for predicting body density of men. Br J Nutr. 1978;40(3):497-504.

13. Siri WE. Techniques for measuring body composition. Washington DC: National Academy Press; 1961.

14. Machado FA, Kravchychyn AC, Peserico CS, da Silva DF, Mezzaroba PV. Incremental test design, peak 'aerobic' running speed and endurance performance in runners. J Sci Med Sport. 2013;16(6):577-82.

15. Peserico CS, Zagatto AM, Machado FA. Reliability of peak running speeds obtained from different incremental treadmill protocols. J Sports Sci. 2014;32(10):993-1000.

16. Borg GA. Psychophysical bases of perceived exertion. Med Sci Sports Exer. 1982;14(5):377-81.

17. Tanaka H, Monahan KD, Seals DR. Age-predicted maximal heart rate revisited. J Am Coll Cardiol. 2001;37(1):153-6.

18. Schabort EJ, Hopkins WG, Hawley JA. Reproducibility of self-paced treadmill performance of trained endurance runners. Int J Sports Med. 1998;19(1):48-51.

19. Currell K, Jeukendrup AE. Validity, reliability and sensitivity of measures of sporting performance. Sports Med. 2008;38(4):297-316.

20. Kuipers H, Rietjens G, Verstappen F, Schoenmakers H, Hofman G. Effects of stage duration in incremental running tests on physiological variables. Int J Sports Med. 2003;24(7):486-91.

21. Peserico CS, Zagatto AM, Machado FA. Evaluation of the best-designed graded exercise test to assess peak treadmill speed. Int J Sports Med. 2015;36(9)729-34. Epub 2015 Apr 14. doi: 10.1055/s-0035-1547225

22. Astrand PO. Experimental studies of physical working capacity in relation to sex and age. Copenhagen: Ejnar Munksgaard; 1952.

23. Dassonville J, Beillot J, Lessard Y, Jan J, André AM, Le Pourcelet C, et al. Blood lactate concentrations during exercise: effect of sampling site and exercise mode. J Sports Med Phys Fitness. 1998;38:(1)39-46.

24. Moran P, Prichard JG, Ansley L, Howatson G. The influence of blood lactate sample site on exercise prescription. J Strength Cond Res. 2012;26:563-7.

25. Hopkins WG, Marshall SW, Batterham AM, Hanin J. Progressive statistics for studies in sports medicine and exercise science. Med Sci Sports Exerc. 2009;41(1):3-13.

26. Machado FA, Kravchychyn ACP, Peserico CS, da Silva DF, Mezzaroba PV. Effect of stage duration on maximal heart rate and post-exercise blood lactate concentration during incremental treadmill tests. J Sci Med Sport. 2013;16(3):276-80.

27. Duncan GE, Howley ET, Johnson BN. Applicability of VO2max criteria: discontinuous versus continuous protocols. Med Sci Sports Exerc. 1997;29(2):273-8.

28. Achten J, Jeukendrup A. Heart rate monitoring: applications and limitations. Sports Med. 2003;33(7):517-38.

29. Eston R. Use of ratings of perceived exertion in sports. Int J Sports Physiol Perform. 2012;7(2):175-82.

30. Gass GC, Rogers S, Mitchell R. Blood lactate concentration following maximum exercise in trained subjects. Br J Sports Med. 1981;15(3):172-6.

31. Baxter-Jones ADG, Eisenmann JC, Sherar LB. Controlling for maturation in pediatric exercise science. Pediatr Exerc Sci. 2005;17(1):18-30.

32. Armstrong N, McManus AM. Physiology of elite young male athletes. Med Sport Sci. 2011;56:1-22. 
33. Izquierdo M, Hakkinen K, Anton A, et al. Maximal strength and power, endurance performance, and serum hormones in middle-aged and elderly men. Med Sci Sports Exerc. 2001;33(9):1577-87.

34. Mattern CO, Gutilla MJ, Bright DL, Kirby TE, Hinchcliff KW, Devor ST. Maximal lactate steady state declines during aging process. J Appl Physiol. 2003;95(6):2576-82.

35. Strupler M, Mueller G, Perret C. Heart rate-based lactate minimum test: a reproducible method. Br J Sports Med. 2009;43(6):432-6.

36. Chiba T, Ishii H, Takahashi S, Yano T. Relationship between blood lactate and hyperventilation during high-intensity constant-load exercise in heat. Biol Sport. 2011;28(3):159-63.

\section{Acknowledgements}

The authors would like to thank the Coordenação de Aperfeiçoamento de Pessoal de Nível Superior - CAPES, Brazil. We also kindly thank Dr. Kristi B. Adamo from the School of Human Kinetics at University of Ottawa, On, Canada for the complete English review of the manuscript.

\begin{tabular}{r|r} 
ADDRESS & \\
Fabiana Andrade Machado & \\
Department of Physical Education & Submitted: 12/01/2015 \\
State University of Maringá & 1st. Review: 10/06/2015 \\
Av. Colombo, 5790 - Jardim Universitário & 2nd. Review: 14/10/2015 \\
87020.900 - Maringá - Paraná - BRAZIL & Accepted: 28/10/2015 \\
e-mail: famachado@uem.br, & \\
famachado_uem@hotmail.com &
\end{tabular}


